\title{
Explaining Tax Non-Compliance from a Neo-Institutionalist Perspective: Some Lessons from a Public Opinion Survey in Turkey
}

Ayşegül KAYAOĞLU (https://orcid.org/0000-0003-1484-184X), Department of Economics, İstanbul Technical University, Turkey; Economic Research Forum (ERF), Egypt; e-mail: kayaogluyilmaz@itu.edu.tr

Colin C. WILLIAMS (https://orcid.org/0000-0002-3610-1933), Department of Management, University of Sheffield, United Kingdom; e-mail: c.c.williams@sheffield.ac.uk

\section{Neo-Kurumsal Perspektif ile Vergi Uyumsuzluğunu Anlamak: Türkiye'deki Bir Kamuoyu Araştırmasından Bulgular}

\begin{abstract}
Conventionally, those engaging in tax non-compliance are explained as rational economic actors doing so when the benefits outweigh the costs. However, many individuals are still compliant to their tax regimes even when the pay-off from tax evasion is greater than the costs. The result is the emergence of a social actor perspective that gives primacy to tax morale when explaining tax noncompliance. Through the lens of neo-institutionalist theory, this approach argues that citizens behave in ways that reflect the normative, cultural-cognitive and regulatory rules of their institutional environments. To test this theory, we have analyzed a representative micro survey of 2,528 citizens in Turkey. The finding we have obtained in this paper using an econometric analysis is that high tax morale is significantly more likely when there is trust in government (the normative dimension), feeling of belonging to the nation (the cultural-cognitive dimension) and perceptions of the risk and severity of punishment (regulatory-instrumental dimension). It displays the importance of the tax morale approach when explaining and tackling tax non-compliance in Turkey.
\end{abstract}

Keywords

Informal Sector, Tax Morale, Tax Evasion, Institutional Theory, Turkey, South-East Europe.

JEL Classification Codes : $\quad$ H26, J46, K42, O17, P37.

\section{$\ddot{\mathbf{O z}}$}

Vergi uyumsuzluğu sergileyenler, genellikle bu davranışları getirileri götürülerinden ağır bastığında sergileyen rasyonel karar alıcılar olarak değerlendirilir. Buna karşın hala pek çok birey, vergi kaçırmanın kazancı maliyetinden büyük olmasına karşın kendilerine uygulanan vergi rejimlerine uyum göstermektedir. Sonuçta ise vergi uyumsuzluğunu açıklamada karşımıza vergi ahlakına öncelik veren bir sosyal aktör yaklaşımı çıkmaktadır. Konuya Neo-Kurumsal Teori penceresinden bakan bu yaklaşım, vatandaşların kurumsal çevrelerinin normatif, kültürel-bilişsel ve düzenleyici kurallarını yansıtır şekilde davrandığını öne sürmektedir. Bizler bu teoriyi test etmek için Türkiye'de 2,528 vatandaşla yapılmış temsili bir veriyi inceledik. Bu çalışmada ekonometrik bir analizle ulaştığımız bulgu, yüksek vergi ahlakının hükümete güven (normatif boyut), ulusal aidiyet hissi (kültürel-bilişsel boyut) ve risk ve cezanın ağırlığının algılandığı (düzenleyici-araçsal boyut) durumlarda anlamlı biçimde daha fazla olası yönde olduğudur. Bu da Türkiye'de vergi uyumsuzluğunu anlamak ve onunla mücadele etmek için vergi ahlakı yaklaşımının önemini göstermektedir. 


\section{Introduction}

To explain tax non-compliance, the conventional approach has been to view taxpayers as rational economic actors who engage in tax non-compliance when the benefits outweigh the expected costs (Allingham \& Sandmo, 1972). However, many have been found to not participate in tax non-compliance even when the rational economic decision would be to do so (Kirchler, 2007; Murphy, 2008; Murphy \& Harris, 2007; Williams \& Krasniqi, 2017, 2018). The outcome has been the emergence of a new social actor perspective which gives primacy to tax morale when explaining tax non-compliance (Webb et al., 2009, 2013; Williams, 2018; Williams et al., 2014). Grounded in neo-institutionalist theory (Scott, 2014), this argues that citizens behave in ways which reflect the regulatory, normative and cognitive rules of their institutional environments (Kirchler, 2007; Murphy, 2008; Torgler, 2007, 2012; Williams \& Horodnic, 2015a, 2015b, 2016a, 2016b). Whether citizens possess a high tax morale, namely an intrinsic motivation to pay taxes (Torgler \& Schneider, 2007), therefore, is hypothesised to be closely associated with whether they conform to the normative, cultural-cognitive and regulatory-instrumental rules (Scott, 2014). The aim of this paper is to test this hypothesis in the Turkish context with a high level of informal economic activity.

As such, this paper advances the emergent tax morale approach in three ways. Firstly, and empirically, a significant positive relationship is identified between high tax morale and trust in government (the normative dimension), feeling of belonging to the nation (the cultural-cognitive dimension) and perceptions of the risk and severity of punishment (regulatory-instrumental dimension). Secondly, therefore, the theoretical basis of this tax morale approach is advanced by embedding it in a neo-institutional framework and showing that citizens behave in ways which reflect the regulatory, normative and cognitive rules of their institutional environments. Thirdly, and finally, from a policy viewpoint, this paper highlights the need to complement the currently dominant policy approach, which seeks to increase the costs of tax non-compliance by increasing the penalties and risks of detection, with a policy approach that seeks to improve tax morale.

To achieve this, the following section reviews the emergent literature explaining tax non-compliance from a tax morale perspective to formulate our hypotheses regarding the relationship between tax morale and the normative, cultural-cognitive and regulatoryinstrumental rules. To evaluate these hypotheses, section 3 then summarizes the data used, namely KONDA Barometer, a public opinion survey of 2,528 citizens in Turkey. Section 4 then reports the empirical findings, while last section summarises both theoretical and policy implications.

\section{Tax Morale and Neo-Institutional Theory: Literature Review and Hypotheses Development}

For more than five decades, a rational economic actor approach has been the dominant way of explaining tax non-compliance. Originating in a seminal paper by 
Allingham and Sandmo (1972), this argues that tax payers are non-compliant when the benefits are greater than the expected costs of being detected and fined. Thus, tax payers are regarded as rational actors who weigh up the benefits and costs and, act in a non-compliant manner when the pay-off is greater than the expected costs (e.g., Horodnic, 2018; ILO, 2017; Williams, 2014, 2018). However, the major criticism of this rational economic actor approach is that many tax payers remain compliant even when benefits of being a noncompliant far outweigh the costs, suggesting that they should be some other explanations for their behaviours (Kirchler, 2007; Murphy, 2008; Murphy \& Harris, 2007; Williams \& Krasniqi, 2017, 2018).

To explain why tax payers are compliant even when the pay-off is greater than the costs, a "tax morale" approach has emerged. This asserts that tax payers have a greater likelihood of being tax non-compliant if they possess a low level of tax morale, by which is meant to have a low intrinsic motivation to pay tax (Torgler, 2007, 2012). To provide a theoretical basis to this conceptualisation, inspiration has been drawn from neoinstitutionalist theory (Scott, 2014). This theory views institutions as the rules of the game and, citizens as shaped by the institutional environments in which they are embedded.

According to Scott (2014), such institutional environments comprise three components, or pillars, namely the regulative, normative and cultural-cognitive. The regulatory pillar can be understood as the formal rules, laws and associated sanctions that promote certain behaviours and restrict others. The regulatory pillar thus relates to formal rules about, for example, the payment of taxation, declaring work, the terms and conditions of employment, and so forth. The second pillar, namely normative pillar, refers to wider norms and values present in a society about what constitutes appropriate and acceptable behaviour. The final one, namely cultural-cognitive pillar, relates to how certain behaviours become taken for granted based on shared understandings. This relates to how informal activities are enacted unintentionally, for instance routine purchasing from an informal vendor, or not expecting or asking for receipts. Indeed, to see the existence of this culturalcognitive pillar, one has only to consider how informal practices are often referred to as 'cultural' or culturally embedded, such as when the populations of countries state that tax non-compliance is part of, for example, the Balkan mind-set, Slavic culture, and so forth, or when non-compliance is sometimes stated to be part of a national culture.

This neo-institutionalist theoretical framework therefore posits that the population behaves in ways which reflect the regulatory, normative and cognitive rules of their institutional environments, adherence to which ensures legitimacy. In the regulatory pillar, this legitimacy is gained through compliance with legal requirements; in the normative pillar it is based on conformity with a moral basis; and, in the cultural-cognitive pillar it comes from adopting a common frame of meaning or approach (Scott, 2014). It is, thus, suggested that institutions exert pressure for compliance through mechanisms of different variants of isomorphism with each of the pillars.

Coercive isomorphism is largely associated with the formal regulatory institutional pillar and relates to providing either 'sticks' which detect and punish non-compliant 
behaviour or 'carrots' to reward and encourage compliant behaviour and a commitment to compliance (Williams, 2014). Normative isomorphism meanwhile is associated with the normative pillar and pressures to conform to wider societal expectations. Finally, mimetic isomorphism is related to the cultural-cognitive pillar, whereby organisations and individuals act in ways that reflect shared understandings and common beliefs, and which are culturally supported (Williams, 2018).

Regarding the normative dimension, therefore, tax morale is affected by the perceived legitimacy of the state, and whether there is trust in government. Paying taxes is a social obligation towards the state. Citizens pay taxes to support the state. However, the state is expected to act in a trustworthy and fair manner in return, a logic that Frey and Torgler (2007) label "conditional cooperation". Indeed, previous studies have widely asserted that tax morale is highly correlated with trust in government (Andriani, 2016; Chan et al., 2018; Daude et al., 2012; Ibrahim et al., 2015; Kondelaji et al., 2016; Leonardo, 2011; Li, 2010; Ristovska et al., 2013; Torgler, 2012; Torgler \& Schaffner, 2007; Torgler \& Schneider, 2004; Trüdinger \& Hildebrandt, 2013; Vythelingum et al., 2017). To evaluate this normative pillar, therefore, the following hypothesis is tested:

Normative hypothesis (H1): Individuals who express higher trust in government have higher tax morale.

In terms of the cognitive-cultural dimension, meanwhile, there is a widespread view that tax morale is affected by the strength of a citizen's identification with the national polity. A shared concept of belonging to this polity motivates some individuals to pay taxes as a way of contributing to the wider community to which they belong. Previous studies, for example, have revealed that patriotism and nationalism (i.e., identification with the country) promote tax morale because they imply a greater attachment to the nation (Bilgin, 2014; Kondelaji et al., 2016; Leonardo \& Martinez-Vazquez, 2016; MacGregor \& Wilkinson, 2015; Martinez-Vazquez \& Torgler, 2009; Martins \& Gomes, 2014; Ristovska et al., 2013; Trüdinger \& Hildebrandt, 2013). When citizens view themselves more as a citizen of a country, rather than a member of an ethnic community or a religious sect, then they will be more likely to pay their taxes to the government of that country to which they view themselves as belonging. To test this cultural/cognitive pillar, therefore, the following hypothesis is tested:

Cultural-cognitive hypothesis (H2): Individuals who identify more strongly with their country have higher tax morale.

About the regulatory/instrumental dimension which refers to the regulatory role of formal institutions in shaping effective explicit constraints on human behaviour, the belief is that "individuals conform to laws and rules because they seek the attendant rewards or wish to avoid sanctions" (Scott, 2014: 63). It is, therefore, typically adopted by institutional economics (Williamson, 2000) and, more broadly, by rational choice theory scholars (Becker, 1968). Contrary to the findings about the previous pillars' relation with tax morale, there is no convergence in findings related to regulatory-instrumental pillar's role. Although 
some scholars find that increasing penalties and the probability of detection increases tax morale (Mas'ud et al., 2015; Mazzolini et al., 2017), there are also findings about insignificant association (Shaw et al., 2008; Williams \& Franic, 2015, 2016). There are even some studies suggesting that it leads to lower tax morale (Hofmann et al., 2017; Kaplanoglou \& Rapano, 2015; Murphy, 2005, 2008; Murphy \& Harris, 2007). To test this regulatory / instrumental pillar, therefore, the following hypothesis is tested in the Turkish context:

Regulatory/instrumental hypothesis (H3): Individuals who are risk averse (and thus more responsive to deterrence policies) have higher tax morale.

In addition to the roles of these normative, cultural and regulatory pillars on tax morale, an economic perspective is also included to have a wider view on the issue of tax morale. Indeed, previous studies have revealed not only that the level of economic development is positively correlated with tax morale (Doerrenberg \& Peichl, 2010; Gerstenbluth et al., 2012; Williams \& Krasniqi, 2017; Williams \& Martinez, 2014) but also that higher satisfaction with one's financial situation is significantly associated with higher tax morale (Alasfour et al., 2016; D’Attoma, 2015; Filippin et al., 2013; Ibrahim et al., 2015; Kondelaji et al., 2016; Martins \& Gomes, 2014; Ristovska et al., 2013; Williams \& Horodnic, 2016c; Windebank \& Horodnic, 2016). To test this economic dimension, therefore, the following hypothesis is tested:

Economic hypothesis (H4): Individuals who have higher expectations of personal economic difficulty have lower tax morale.

\section{Data and Methodology}

To evaluate these hypotheses, this paper examines micro-level public opinion data collected in Turkey by KONDA Research in September 2012. In total, 2,528 individuals were interviewed in 12 regions of Turkey. The sample was prepared by stratifying the data on population and education levels of neighbourhoods and villages based upon the AddressBased Population Registration System and general election results of 12 June 2011. This resulted in interviews in 29 provinces, 93 districts and 150 neighbourhoods/villages.

Given that the dependent variable in the empirical model is a binary variable, Probit regression model is here employed as the estimation technique. Table 1 presents the descriptive statistics of the variables that are used in the empirical models. The mean variance inflation factor (VIF) for all the independent variables (including regional fixed effects) is 1.53 and, therefore, we can argue that there is not a problem of multicollinearity. The detailed information on the dependent and independent variables are provided below.

\section{Dependent variable}

Tax morale: In the survey, there was one question designed to specifically measure the level of tax morale, which asks respondents to select one of five categories about the statement: "I would cheat on taxes if I knew that I would not be caught." The categories available to select were "definitely wrong", "wrong", "it is neither correct nor wrong", 
"correct", and "definitely correct". As we are interested not in the factors that cause people to choose different categories but rather the factors that are associated with high and low tax morale, we transformed this variable into a dummy variable which is equal to 1 for people with a high tax morale and 0 otherwise. In the dataset without any missing value, $94.45 \%$ of individuals either responded "definitely wrong" or "wrong" to this statement. However, we know from the literature that the size of informal economy in Turkey ranges from $30 \%$ to $52 \%$ according to different studies. Schneider and Williams (2013) argue, for example, that level of shadow economy in Turkey was the highest among the OECD countries in 2007. Therefore, $94.45 \%$ of people saying that they have a high tax morale is not in line with the macro findings regarding tax non-compliance which leads us to consider only people who say "definitely wrong" as having a high tax morale and the rest are categorized as having a low tax morale". Moreover, binary variable transformation decreases the level of measurement error due to subjective evaluations of choosing different answer categories. As can be seen in Table 1, 40.9\% of people are categorized as not having "high tax morale" which is close to the estimates for the informal economy in Turkey.

\section{Independent Variables}

The key independent variables used to evaluate the four hypotheses respectively are the following.

To evaluate the normative hypothesis (H1) that individuals who express higher trust in government have higher tax morale, the variable used is:

- Trust in Government: This is a five-category variable that asks the respondents about their level of trust in the government. At one extreme is the answer "no trust at all" coded as 1 and at the other extreme the answer of "totally trust" coded as 5.

To evaluate the cultural/cognitive hypothesis (H2) that individuals who identify more strongly with their country have higher tax morale, the variable used is:

- Identity Preferences: In the questionnaire, a specific question is asked to understand the identity preferences of respondents. The question is "Which one describes you the best? Which identity of yours stands first among all?". There are three possible answers to this question: "citizenship of Turkey"2, "my ethnic

1 The analysis is also replicated with that broader definition of tax morale. The signs and significance levels of variables are very similar. The results are available upon request.

2 This is different than "Turkishness" because it signifies not a specific ethnicity or religion but rather being a member of the country. It has been used as an umbrella term in Turkey after the "Kurdish opening" of 2000 s with an aim to improve the social cohesion in the country which has ethnic conflict for long years; though it argued to be an unsuccessful attempt (Kayaoglu, 2017). 
identity" or "my religion/sect". Each of the three categories are transformed into dummy variables and added to the empirical models to test the hypothesis.

To evaluate the regulatory/instrumental hypothesis (H3) that individuals who are more risk averse have higher tax morale, we used the following variable:

- Risk aversion level: This is a 5-category variable, which includes answers according to the agreement level of respondents to the statement of "I do not like taking risk and I avoid taking it". It is coded as 1 if respondents stated "definitely wrong" and 5 if they stated "definitely correct". Thus, the higher the value of this variable, the higher also the risk aversion level.

Table: 1

\section{Descriptive Statistics}

\begin{tabular}{|c|c|c|c|c|}
\hline Variable & Mean & Std. Dev. & Min & Max \\
\hline Tax morale & .591 & .492 & 0 & 1 \\
\hline Trust in Government & 2.891 & 1.536 & 1 & 5 \\
\hline \multicolumn{5}{|l|}{ Identity Preference: } \\
\hline Citizenship of Turkey & .649 & .477 & 0 & 1 \\
\hline Ethnic Identity & .094 & .292 & 0 & 1 \\
\hline Religious Identity & .256 & .436 & 0 & 1 \\
\hline Expectation of personal economic difficulty & .526 & .499 & 0 & 1 \\
\hline Expectation of national economic crisis & .509 & .500 & 0 & 1 \\
\hline Risk aversion level & 3.265 & 1.238 & 1 & 5 \\
\hline Female & .495 & .500 & 0 & 1 \\
\hline Age & 38.799 & 14.674 & 15 & 85 \\
\hline \multicolumn{5}{|l|}{ Education level: } \\
\hline Below high-school & .534 & .498 & 0 & 1 \\
\hline High-school degree & .299 & .458 & 0 & 1 \\
\hline Above high-school & .165 & .372 & 0 & 1 \\
\hline Ethnicity ( $1=$ Turk, $0=$ other) & .840 & .366 & 0 & 1 \\
\hline Religiosity & 3.858 & 1.992 & 1 & 7 \\
\hline Income & 3.574 & 1.157 & 1 & 6 \\
\hline Self-employed & .085 & .279 & 0 & 1 \\
\hline \multicolumn{5}{|l|}{ Type of residence: } \\
\hline Rural & .205 & .404 & 0 & 1 \\
\hline Urban & .288 & .453 & 0 & 1 \\
\hline Metropolitan & .507 & .500 & 0 & 1 \\
\hline \multicolumn{5}{|l|}{ Regional Dummies: } \\
\hline Istanbul & .189 & .392 & 0 & 1 \\
\hline West Marmara & .055 & .228 & 0 & 1 \\
\hline Aegean & .168 & .374 & 0 & 1 \\
\hline East Marmara & .106 & .308 & 0 & 1 \\
\hline West Anatolia & .111 & .314 & 0 & 1 \\
\hline Mediterranean & .102 & .303 & 0 & 1 \\
\hline Central Anatolian & .036 & .187 & 0 & 1 \\
\hline West Black Sea & .059 & .237 & 0 & 1 \\
\hline East Black Sea & .034 & .182 & 0 & 1 \\
\hline Northeast Anatolia & .015 & .124 & 0 & 1 \\
\hline Middle east Anatolia & .039 & .193 & 0 & 1 \\
\hline South east Anatolia & .083 & .276 & 0 & 1 \\
\hline
\end{tabular}

Source: Authors' calculations from KONDA Barometer.

To evaluate the economic hypothesis (H4), which argues that individuals who have higher expectations of economic difficulty have lower tax morale, the following two variables are used to assess this at the level of both personal and national economic difficulty: 
- Expectation of personal economic difficulty: This is a dummy variable, which is equal to 1 if respondents expect an economic difficulty in their personal life in the coming months and 0 otherwise.

- Expectation of national economic crisis: This is a dummy variable, which is equal to 1 if respondents state that they expect an economic crisis in Turkey in the coming months and 0 otherwise.

A series of individual-level variables that previous studies reveal are significantly associated with tax morale are included as control variables (derived from the systematic review by Horodnic (2018)). These are:

- Gender: A dummy variable for gender, which is equal to 1 for females and 0 for males.

- Age: A continuous variable that shows the age of respondent.

- Educational level: This is a 3-category variable where the first category is refers to a qualification below high-school level, category 2 denotes high-school diploma and the last category is for an above high-school diploma.

- Ethnicity: This is a dummy variable, where 1 is that the respondent is a Turk and, 0 otherwise which includes $12.32 \%$ Kurds, $0.61 \%$ Arabs and $2.73 \%$ other ethnicities.

- Religiosity: This is a 7-category variable, which asks respondents about the current frequency of going to a mosque/church/synagogue apart from attending ceremonies. The answer ranges from 1 that denotes "not at all" through to 7 which indicates "every day". It is included in the regression models as a continuous variable assuming that the higher the value it has, the more religious is the respondent.

- Income: This is a categorical variable denoting the monthly income level of respondents. It ranges from category 1 for people with a monthly income of below 300 TL in 2012 through to 6 for an income level above 3000 TL. The majority have an income between 700 and 2000 TL. The category 1 has $3.64 \%$ of respondents while $6.81 \%$ of them have reported an income above 3000 TL.

- Self-employed: A dummy variable which is 1 if the respondent is self-employed and 0 otherwise.

- Type of locality: It includes 3 categories, which are rural, urban and metropolitan. These three spatial characteristics are separately included in the regression models as dummy variables.

- Regional dummies: These are dummy variables for 12 geographical regions in Turkey.

\section{Empirical Findings}

To evaluate the hypotheses, we performed an empirical analysis using the public opinion survey data. Table 2 presents the marginal effects of Probit models. We include the 
key independent variables that are used to test each hypothesis step by step. Model 5 is the full model which includes all the covariates together.

Results show that trust in government has a statistically significant and positive association with the probability of having a high tax morale in Turkey (confirming hypothesis H1). Indeed, a one category increase in the level of trust in government increases the probability of having a high tax morale by around 2 percentage points when all other factors are held constant.

Secondly, the cultural/cognitive hypothesis is tested in Model 3 alone and in Model 5 with the other pillar dimensions. To test this hypothesis, we included dominant identity categories that are chosen by respondents where the category of "citizenship of Turkey" is used as the reference category. The results show that individuals who use their ethnicity as the most important identity marker for themselves have a 7 percentage points lower probability of having a high tax morale compared to people who define themselves as citizens of Turkey, ceteris paribus (confirming hypothesis H2). However, religiosity as the most important identity marker does not have a statistically significant association with the probability of having a high tax morale when we control for other factors.

Thirdly, on the regulatory/instrumental perspective, we find that individuals who are risk averse (and thus more responsive to deterrence policies), are significantly more likely to have a high tax morale (confirming hypothesis H3). Indeed, across all models, we see that an increase in their risk aversion level by one unit increases the probability of having a high tax morale by around 4 percentage points when other variables are held constant.

Finally, two different variables are used to test the economic perspective, one of which measures the expectation of personal economic difficulties and the other is a variable about the economic expectations at the country level. We find that expectations about personal economic difficulties are significantly and negatively correlated with a high tax morale. A one unit increase in the expectations of personal economic difficulties lowers the probability of having a high tax morale by 5.3 percentage points in ceteris paribus (confirming H4). However, no significant association exist between expectation of a national economic crisis and tax morale.

Examining the other socio-demographic, economic and spatial independent variables, there are also some important associations identified. These relationships are important for understanding which groups are more likely to have a high tax morale and, therefore, for targeting policies that seek to improve tax morale. Starting with the sociodemographic factors, gender has no association with tax morale. Age, however, has a significant positive relationship with the probability of a high tax morale. Interestingly, the empirical analysis shows no relationship between education and tax morale when other factors are held constant. Therefore, it seems that policies designed to increase the education level of the population would not contribute to a higher level of tax morale and, concomitantly, higher levels of tax compliance. 
Another important finding is about the role of ethnicity on the probability of high tax morale. We find that Turks have a lower probability of a high tax morale compared with other ethnicities where tha latter is dominated by Kurdish ethnicity in Turkey. For example, Model 5 shows that, when all other control variables are held constant, Turks have an 8.6 percentage point's lower probability of having a high tax morale compared to other ethnicities. Moreover, religiosity has a significant positive correlation with the probability of having a high tax morale, although its economic significance is not that large.

Examining the role of individual-level economic factors on tax morale, previous literature argues that factors such as income and self-employment (see Horodnic, 2018) do not have any association with the level of tax morale. However, our analysis reveals that although income is not a statistically significant factor to understand tax morale in Turkey, self-employment have a significantly negative relationship with the probability of possessing a high tax morale. We see that self-employed respondents have 11.7 percentage points lower probability of having a high tax morale when other factors are held constant. According to OECD statistics, 32.4\% of total employment in Turkey is self-employed and, therefore, their tax attitude is very important for the total tax revenue in Turkey.

When we analyse the role of spatial factors on the probability of having a high tax morale, Table 2 reveals that individuals who live in urban areas show an 8.8 percentage point's higher probability of having a high tax morale compared to those in rural areas when other covariates are held constant. However, metropolitan residents have a 7.3 percentage point's lower probability of having a high tax morale. We also included regional dummies into our regression model to control for any region-specific fixed effects. It seems that residents living in Aegean, East Marmara and Central Anatolia have a lower probability of having a high tax morale while respondents living in West Anatolia, Mediterranean, West Black Sea, Northeast Anatolia and South east Anatolia have higher probabilities of possessing a high tax morale.

To understand the role of ethnic background at different income groups on the likelihood of having a high tax morale, we run Model 6 with an addition of interaction variable between ethnicity and income into the full model (Model 5). Table 3 presents the results. It shows that although being a Turk and having a higher level of income has a negative relationship with high tax morale, the strength of these relationships weakens for Turks with a higher level of income.

We also checked the goodness-of-fit of the full model through Lowess smoother. Results presented in Figure 1 show that the model is good in predicting the tax morale as the relationship between predicted and observed probabilities are very similar. Thus, it can be asserted that the model fits the data well. 
Table: 2

Individual Predictors of Tax Morale in Turkey (Marginal effects from Probit models)

\begin{tabular}{|c|c|c|c|c|c|}
\hline & Model 1 & Model 2 & Model 3 & Model 4 & Model 5 \\
\hline \multicolumn{6}{|l|}{ Hypotheses: } \\
\hline $\begin{array}{l}\text { H1. Normative Perspective } \\
\text { Trust in Government }\end{array}$ & & $.021^{* * * *}$ & & & $.015^{* *}$ \\
\hline \multicolumn{6}{|l|}{$\begin{array}{l}\text { H2. Cultural/Cognitive Perspective } \\
\text { (RC: Citizenship of Turkey) }\end{array}$} \\
\hline Ethnic Identity & & & $-.071 *$ & & $-.068 *$ \\
\hline Religious Identity & & & -.030 & & -.041 \\
\hline \multicolumn{6}{|l|}{ H4. Economic Perspective } \\
\hline Expectation of personal economic difficulty & & & & $-.054 * *$ & $-.053 * *$ \\
\hline Expectation of national economic crisis & & & & -.036 & -.022 \\
\hline \multicolumn{6}{|l|}{ H3. Regulatory/Instrumental Perspective } \\
\hline Risk Aversion Level & $.041 * * *$ & $.040 * * *$ & $.040 * * *$ & $.041 * * *$ & $.038^{* * * *}$ \\
\hline \multicolumn{6}{|l|}{ Socio-demographic Factors: } \\
\hline Female & .016 & .009 & .018 & .019 & 016 \\
\hline Age & $.005^{* * *}$ & $.002 * * * *$ & $.002 * * *$ & $.002 * * * *$ & $.002 * * *$ \\
\hline \multicolumn{6}{|l|}{ Education Level (RC: Below high-school) } \\
\hline high school degree & -.005 & .004 & -.006 & -.003 & .000 \\
\hline above high school & .038 & $.055^{*}$ & .033 & .046 & .050 \\
\hline Ethnicity $(1=$ Turk, $0=$ other $)$ & $-.066^{* *}$ & $-.072 * *$ & $-.076 * *$ & $-.070^{* *}$ & $-.086 * * *$ \\
\hline Religiosity & $.015^{* *}$ & $.012 *$ & $.016 * * *$ & $.014 * *$ & $.013^{* *}$ \\
\hline \multicolumn{6}{|l|}{ Economic Factors: } \\
\hline Income & .007 & .007 & $-.038 * * *$ & .001 & .001 \\
\hline Self-employed & $-.113 * * *$ & $-.111 * * *$ & $-.116 * * *$ & $-.115 * * *$ & $-.117 * * *$ \\
\hline \multirow{2}{*}{\multicolumn{6}{|c|}{$\begin{array}{l}\text { Spatial Factors: } \\
\text { Type of locality (RC: rural area) }\end{array}$}} \\
\hline & & & & & \\
\hline urban & $.094 * * *$ & $.090^{* * * *}$ & $.097 * * *$ & $.085^{* * * *}$ & $.088^{* * * *}$ \\
\hline metropolitan & $-.073 * *$ & $-.074 * *$ & $-.077 * *$ & $-.069^{*}$ & $-.073 * *$ \\
\hline \multicolumn{6}{|l|}{ Region FE (RC: Istanbul) } \\
\hline West Marmara & .019 & .024 & .009 & .032 & .023 \\
\hline Aegean & $-.090 * *$ & $-.081 * *$ & $-.090 * *$ & $-.079 *$ & $-.074 *$ \\
\hline East Marmara & $-.172 * * *$ & $-.169^{* * * *}$ & $-.180 * * *$ & $-.165^{* * * *}$ & $-.173^{* * * *}$ \\
\hline West Anatolia & $.140^{* * *}$ & $.143 * * *$ & $.146^{* * * *}$ & $.144 * * *$ & $.151^{* * *}$ \\
\hline Mediterranean & $.162 * * *$ & $.167 * * *$ & $.162 * * *$ & $.172 * * *$ & $.173^{* * * *}$ \\
\hline Central Anatolia & $-.166 * *$ & $-.163 * *$ & $-.163 * *$ & $-.167 * *$ & $-.157 * *$ \\
\hline West Black Sea & $.172^{* * * *}$ & $.174 * * *$ & $.165 * * *$ & $.182 * * *$ & $.176^{* * * *}$ \\
\hline East Black Sea & .037 & .042 & .038 & .047 & .052 \\
\hline Northeast Anatolia & $.155^{*}$ & $.159 * *$ & $.156 \%$ & $.165^{* * *}$ & $.167 * *$ \\
\hline Middle east Anatolia & .031 & .031 & .025 & .011 & .010 \\
\hline South east Anatolia & $.173^{* * *}$ & $.175^{* * * *}$ & $.180 * * *$ & $.171 * * *$ & $.180^{* * * *}$ \\
\hline $\mathrm{R}^{2} /$ Pseudo- $\mathrm{R}^{2}$ & 0.076 & 0.079 & 0.078 & 0.080 & 0.083 \\
\hline BIC & -14789.4 & -14789.6 & -14777.8 & -14786.4 & -14771.5 \\
\hline Hosmer-Lemeshow Test p-value & 0.9455 & 0.5359 & 0.9995 & 0.9364 & 0.9553 \\
\hline Number of Observations & 2,306 & 2,306 & 2,306 & 2,306 & 2,306 \\
\hline
\end{tabular}

Notes. All missing values are eliminated before running the regressions.

$* * *$-value $<0.01, * * p$-value $<0.05$ and $* p$-value $<0.1$.

Source: authors' calculations of 2012 micro-level Public Opinion data.

Table: 3

Individual Predictors of Tax Morale in Turkey (Marginal effects from Probit models)

\begin{tabular}{lrr}
\hline & Model 5 & Model 6 \\
\hline Ethnicity (1=Turk, 0=other) & $-.086^{* * * *}$ & $-.260^{* * * *}$ \\
Income & .001 & $-.051^{* *}$ \\
Ethnicity*Income & & $.061^{* *}$ \\
All other covariates & Yes & Yes \\
\hline $\mathrm{R}^{2} /$ Pseudo- $\mathrm{R}^{2}$ & 0.083 & 0.085 \\
Number of Observations & 2,306 & 2,306 \\
\hline
\end{tabular}

Notes. All missing values are eliminated before running the regressions.

$* * *$-value $<0.01, * * p$-value $<0.05$ and $* p$-value $<0.1$.

Source: authors' calculations of 2012 micro-level Public Opinion data. 
Figure: 1

\section{Lowess Smoother for the Empirical Model}

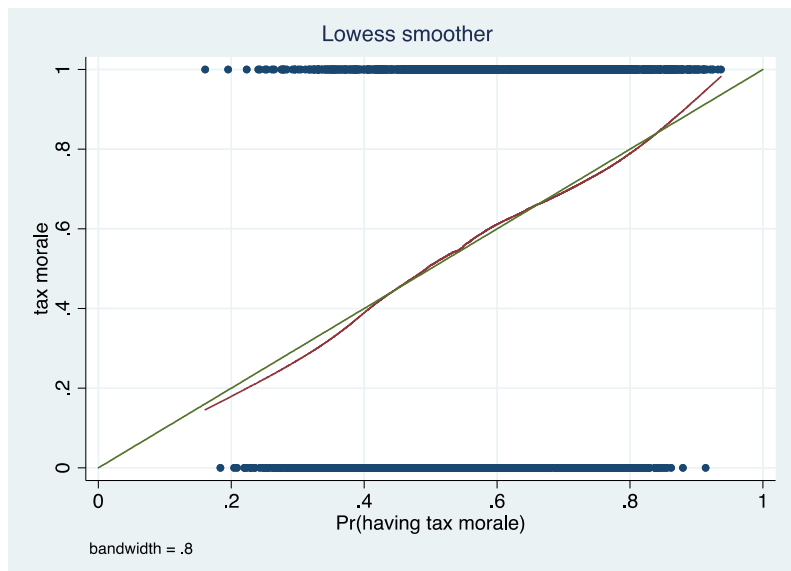

Figure: 2

Predicted Probabilities for Selected Covariates
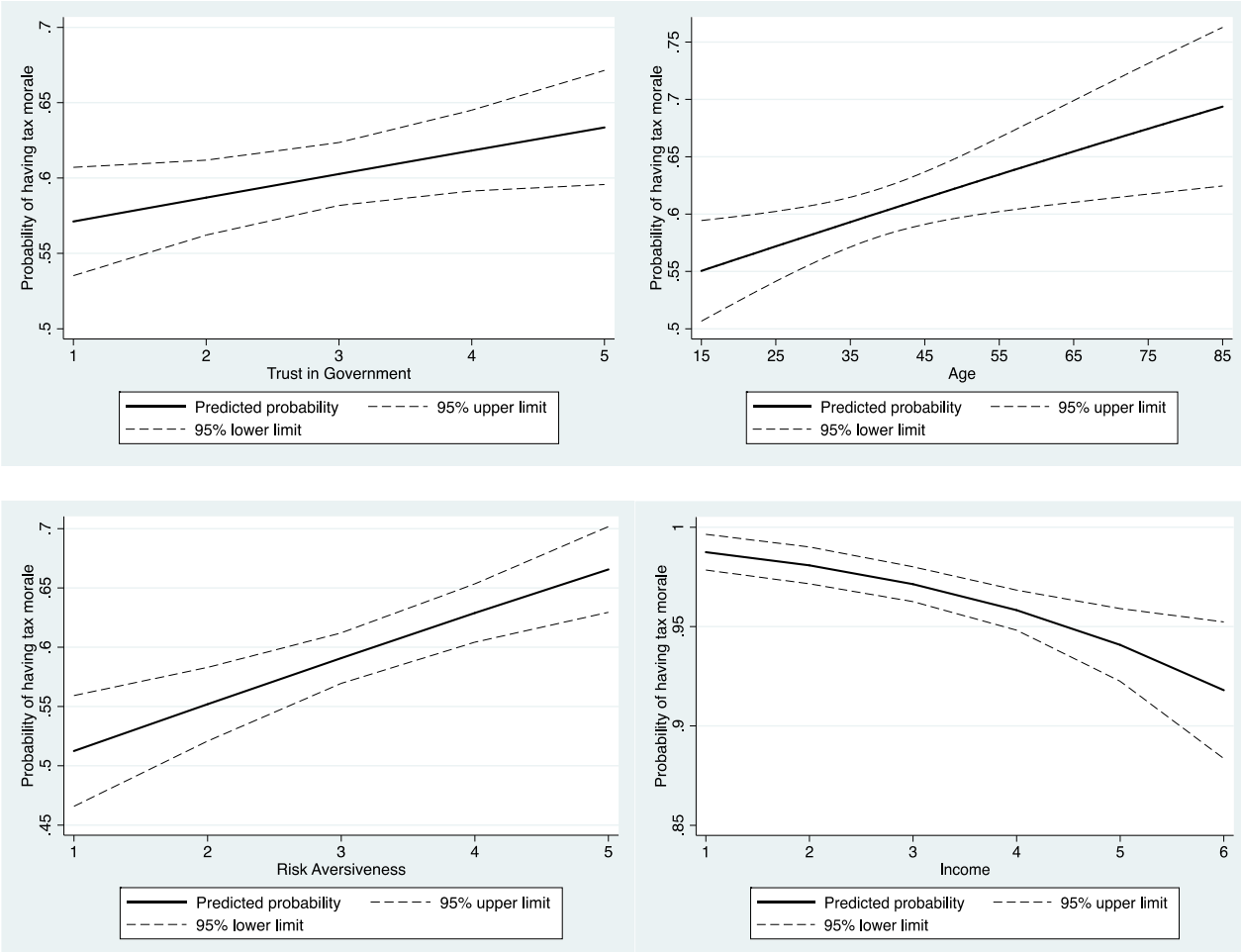
We also presented the predicted probabilities for selected covariates to make it easier to understand their relationship with the probability of having high tax morale instead of only interpreting the point estimates. The top-left figure shows us that if an individual with a lack of trust in government starts to have the highest level of trust in government, then her/his probability of having a high tax morale increases by 5 percentage points. Moreover, our model predicts about an 8-percentage point higher probability of having a high tax morale for a 65-year old individual compared with a 25-year old individual. Interestingly, we observe that the difference between the probability of a high tax morale between a fully risk-averse person and a full risk-taker is 15 percentage points. Thus, we can argue the important role of regulatory/institutional pillar in Turkey even when we control all other factors. Last but not the least, the differences in the probability of having a high tax morale between respondents in the lowest and highest income groups is only 5 percentage points.

\section{Discussion and Conclusions}

This paper has evaluated a new tax morale approach grounded in neo-institutionalist theory. This new approach argues that citizens behave in ways which reflect the regulatory, normative and cognitive rules of their institutional environments. We analysed a public opinion survey conducted in Turkey of 2,528 citizens using econometric methods.

In terms of the theoretical implications, therefore, this paper makes several advances in the tax morale approach. First, a significant positive relationship is identified between high tax morale and trust in government (the normative dimension), feeling of belonging to the nation (the cultural-cognitive dimension) and perceptions of the risk and severity of punishment (regulatory-instrumental dimension), as well as a lack of expectation of personal economic difficulty (economic dimension). Secondly, and importantly, this confirms the usefulness of neo-institutionalist theory when seeking to explain high tax morale. It reveals how, by embedding a tax morale perspective into a neo-institutional framework, one can see citizens behave in ways which reflect the regulatory, normative and cognitive rules of their institutional environments. Thirdly, however, it also reveals that tax morale is conditional upon the perceived individual economic well-being, which will need to be further investigated in future studies.

Examining the implications for policy, this paper reveals that the dominant rational economic actor policy approach needs to be complemented with other policy measures to improve tax morale in Turkey. The probit regression analysis reveals that not only sociodemographic, economic and spatial characteristics but also ethnicity, identity preference and the level of trust in government play a role in shaping the tax morale of individuals in Turkey. Thus, increasing the risk of detection or level of sanctions by enforcement authorities is not the only promising way to solve tax non-compliance in Turkey. Rather, there is a need for a more comprehensive approach. This should include the development of policies that encourage social cohesion and trust in political institutions in Turkey. Moreover, specific tax incentives for self-employed people might increase their tax compliance. Last but not the least, regional campaigns can be designed to increase the awareness of people especially in regions with low levels of tax morale. 
Despite these clear theoretical and policy implications, this paper nevertheless has limitations. Firstly, it reports results for only one country, namely Turkey. Future research, therefore, needs to evaluate whether similar significant associations are identified when conducting surveys not only in other nations and European regions but also beyond. Secondly, although this study reveals that tax morale is significantly associated with regulatory, normative and cognitive institutions, as well as an economic dimension, future quantitative and in-depth qualitative research is required to evaluate systematically a broader array of these dimensions. This will also help governments to pursue more targeted initiatives to improve tax morale and reduce tax non-compliance.

In sum, this paper has displayed the importance of the tax morale approach, grounded in neo-institutional theory, when explaining and tackling tax non-compliance in Turkey. If this now encourages similar analyses in other nations and European regions to build the evidences regarding the validity of this theoretical perspective, then this paper will have achieved a primary intention. If the results presented here are used in the design of policies to tackle tax non-compliance, with greater emphasis put on addressing the low tax morale, then it will have achieved its broader intention.

\section{References}

Alasfour, F. \& M. Samy \& R. Bampton (2016), "The determinants of tax morale and tax compliance: evidence from Jordan", in: J. Hasseldine (ed.), Advances in Taxation, Bingley: Emerald, 125-171.

Allingham, M.G. \& A. Sandmo (1972), "Income tax evasion: a theoretical analysis", Journal of Public Economics, 1(3-4), 323-338.

Andriani, L. (2016), “Tax morale and prosocial behaviour: evidence from a Palestinian survey”, Cambridge Journal of Economics, 40(3), 821-841.

Becker, G. (1968), “Crime and punishment: An economic approach”, Journal of Political Economy, $76(2), 169-217$.

Bilgin, C. (2014), "Determinants of tax morale in Spain and Turkey: an empirical analysis", European Journal of Government and Economics, 3(1), 60-74.

Chan, H.F. \& M.W. Supriyadi \& B. Torgler (2018), “Trust and tax morale”, in: E.M. Uslaner (ed.), The Oxford Handbook of Social and Political Trust, Oxford: Oxford University Press, 42-61.

D’Attoma, J. (2015), “A nation divided: assessing the regional effects of institutions, social capital, and civic culture on tax morale in Italy", Missouri: Dissertation Thesis, University of Missouri-St. Louis, St. Louis.

Daude, C. \& H. Gutiérrez \& Á. Melguizo (2012), “What drives tax morale?”, Paris: Working Paper No. 35, OECD Development Centre, OECD.

Doerrenberg, P. \& A. Peichl (2010), "Progressive taxation and tax morale”, Bonn: IZA Discussion Paper No. 5378, The Institute for the Study of Labor (IZA).

Filippin, A. \& C.V. Fiorio \& E. Viviano (2013), "The effect of tax enforcement on tax morale", European Journal of Political Economy, 32, 320-331.

Frey, B.S. \& B. Torgler (2007), "Tax morale and conditional cooperation”, Journal of Comparative Economics, 35(1), 136-159. 
Gerstenbluth, M. \& N. Melgar \& J.P. Pagano \& M. Rossi (2012), "How do inequality affect tax morale in Latin America and Caribbean?", Revista de Economia del Rosario, 15(2), 123 135.

Hofmann, E. \& B. Hartl \& K. Gangl \& M. Hartner-Tiefenthaler \& E. Kirchler (2017), “Authorities’ coercive and legitimate power: the impact on cognitions underlying cooperation", Frontiers in Psychology, 8(5), 121-134.

Horodnic, I.A. (2018), “Tax morale and institutional theory: a systematic review", International Journal of Sociology and Social Policy, <https://doi.org/10.1108/IJSSP-03-2018-0039>, 25.05.2019.

Ibrahim, M. \& A. Musah \& A. Abdul-Hanan (2015), "Beyond enforcement: what drives tax morale in Ghana?", Humanomics, 31(4), 399-414.

ILO (2017), ILO approach to strategic compliance for labour inspectorates, Geneva: ILO.

Kaplanoglou, G. \& V.T. Rapanos (2015), "Why do people evade taxes? New experimental evidence from Greece", Journal of Behavioral and Experimental Economics, 56, 21-32.

Kayaoglu, A. (2017), "Determinants of trust in Turkey", European Societies, 19(4), 492-516.

Kirchler, E. (2007), The economic psychology of tax behaviour, Cambridge: Cambridge University Press.

Kondelaji, M.H. \& M. Sameti \& H. Amiri \& R. Moayedfar (2016), "Analyzing determinants of tax morale based on social psychology theory: case study of Iran", Iranian Economic Review, 20(4), 581-598.

Leonardo, G. \& J. Martinez-Vazquez (2016), "Politicians, bureaucrats, and tax morale: what shapes tax compliance attitudes?", Atlanta: International Studies Program Working Paper 16-08, Andrew Young School of Policy Studies, Georgia State University.

Leonardo, G.M. (2011), "Politics and tax morale. The role of trust, values, and beliefs, in shaping individual attitudes towards tax compliance", Atlanta: Dissertation Thesis, Georgia Institute of Technology, Georgia State University.

Li, S.X. (2010), "Social identities, ethnic diversity, and tax morale", Public Finance Review, 38(2), $146-177$

MacGregor, J. \& B. Wilkinson (2012), "The effect of economic patriotism on tax morale and attitudes toward tax compliance", Advances in Taxation, 20, 159-180.

Martinez-Vazquez, J. \& B. Torgler (2009), "The evolution of tax morale in modern Spain”, Journal of Economic Issues, 43(1), 1-28.

Martins, A. \& C. Gomes (2014), "Tax morale, occupation and income level: an analysis of Portuguese taxpayers", Journal of Economics, Business and Management, 2(2), 112-116.

Mas'ud, A. \& N.A.A. Manaf \& N. Saad (2015), "Testing assumptions of the 'slippery slope framework' using cross-country data: evidence from sub-Saharan Africa”, International Journal of Business and Society, 16(3), 408-421.

Mazzolini, G. \& L. Pagani \& A. Santoro (2017), "The deterrence effect of real-world operational tax audits", Milan: DEMS Working Paper Series No. 359, Department of Economics, Management and Statistics, University of Milan-Bicocca.

Murphy, K. \& N. Harris (2007), "Shaming, shame and recidivism: a test of reintegrative shaming theory in the white-collar crime context", The British Journal of Criminology, 47(6), 900-917. 
Murphy, K. (2005), "Regulating more effectively: the relationship between procedural justice, legitimacy, and tax non-compliance", Journal of Law and Society, 32(4), 562-589.

Murphy, K. (2008), “Enforcing tax compliance: to punish or persuade?”, Economic Analysis \& Policy, 38(1), 113-135.

Ristovska, M. \& N. Mojsoska-Blazevski \& M. Nikolov (2013), "An alternative view to the tax evasion: the effect of tax morale on paying taxes in Macedonia and EU countries", Serbian Journal of Management, 8(2), 169-183.

Schneider, F. \& C.C. Williams (2013), The shadow economy, London: Institute of Economic Affairs.

Scott, R. (2014), Institutions and organizations ( $4^{\text {th }}$ ed.), Thousand Oaks: Sage

Shaw, J. \& J. Slemrod \& J. Whiting (2008), Administration and Compliance, Oxford: Oxford University Press.

Torgler, B. \& F. Schneider (2004), "Does culture influence tax morale? evidence from different European countries", Basel: Working Paper no. 2004-17, Center for Research in Economics, Management and the Arts.

Torgler, B. \& F. Schneider (2007), "What shapes attitudes toward paying taxes? evidence from multicultural European countries", Social Science Quarterly, 88(2), 443-470.

Torgler, B. \& K. Murphy (2004), "Tax morale in Australia: what shapes it and has it changed over time?", Journal of Australian Taxation, 7(2), 298-335.

Torgler, B. \& M. Schaffner (2007), "Causes and consequences of tax morale: an empirical investigation”, Basel: Working Paper no. 2007-11, Center for Research in Economics, Management and the Arts.

Torgler, B. (2007), Tax compliance and morale. A theoretical and empirical analysis, Cheltenham: Edward Elgar.

Torgler, B. (2012), "Tax morale, Eastern Europe and European enlargement”, Communist and PostCommunist Studies, 45(1-2), 11-25.

Trüdinger, E.-M. \& A. Hildebrandt (2013), "Causes and contexts of tax morale: rational considerations, community orientations, and communist rule”, International Political Science Review, 34(2), 191-209.

Vythelingum, P. \& H. Soondram \& B. Jugurnath (2017), “An assessment of tax morale among Mauritian taxpayers", Journal of Accounting and Taxation, 9(1), 1-10.

Webb, J.W. \& G.D. Bruton \& L. Tihanyi \& R.D. Ireland (2013), "Research on entrepreneurship in the informal economy: framing a research agenda", Journal of Business Venturing, 28, 598-614.

Webb, J.W. \& L. Tihanyi \& R.D. Ireland \& D.G. Sirmon (2009), "You say illegal, I say legitimate: entrepreneurship in the informal economy", Academy of Management Review, 34(3), 492-510.

Williams, C.C. (2018), Entrepreneurship in the Informal Sector: an institutional perspective, London: Routledge.

Williams, C.C. (2014), Confronting the Shadow Economy: evaluating tax compliance and behavior policies, Cheltenham: Edward Elgar.

Williams, C.C. \& J. Franic (2015), "Tackling the propensity towards undeclared work: some policy lessons from Croatia", South East European Journal of Economics and Business, 10 (1): 18-31. 
Williams, C.C. \& J. Franic (2016), "Explaining participation in the informal economy in postsocialist societies: a study of the asymmetry between formal and informal institutions in Croatia", Journal of Contemporary Central and Eastern Europe, 24(1), 51-65.

Williams, C.C. \& I.A. Horodnic (2015a), "Evaluating the prevalence of the undeclared economy in Central and Eastern Europe: an institutional asymmetry perspective", European Journal of Industrial Relations, 21(4), 389-406.

Williams, C.C. \& I.A. Horodnic (2015b), "Explaining and tackling the shadow economy in Estonia, Latvia and Lithuania: a tax morale approach", Baltic Journal of Economics, 15(2), 81-98.

Williams, C.C. \& I.A. Horodnic (2016a), "An institutional theory of the informal economy: some lessons from the United Kingdom”, International Journal of Social Economics, 43(7), 722-738.

Williams, C.C. \& I.A. Horodnic (2016b), "Cross-country variations in the participation of small businesses in the informal economy: an institutional asymmetry explanation", Journal of Small Business and Enterprise Development, 23(1), 3-24.

Williams, C.C. \& I.A. Horodnic (2016c), "Tackling the undeclared economy in the European Union: an evaluation of the tax morale approach", Industrial Relations Journal, 47(4), 322-340.

Williams, C.C. \& B. Krasniqi (2018), "Explaining entrepreneurship in the informal economy: an institutionalist perspective", Journal of Developmental Entrepreneurship, 23(2), $10.1142 / \mathrm{S} 1084946718500115$.

Williams, C.C. \& B. Krasniqi (2017), "Evaluating the individual- and country-level variations in tax morale: evidence from 35 Eurasian countries", Journal of Economic Studies, 44(5), 816832.

Williams, C.C. \& Á. Martinez (2014), "Explaining cross-national variations in tax morality in the European Union: an exploratory analysis", Studies of Transition States and Societies, 6(1), 5-18.

Williams, C.C. \& J. Franic \& R. Dzhekova (2014), "Explaining and tackling the undeclared economy in Bulgaria: an institutional asymmetry perspective", The South-East European Journal of Economics and Business, 9(2), 33-45.

Williamson, O. (2000), "New institutional economics", Journal of Economic Literature, 38(3), 595613.

Windebank, J. \& I.A. Horodnic (2017), "Explaining participation in undeclared work in France: lessons for policy evaluation", International Journal of Sociology and Social Policy, 37(3-4), 203-217. 
Kayaoğlu, A. \& C.C. Williams (2020), "Explaining Tax Non-Compliance from a Neo-Institutionalist Perspective: Some Lessons from a Public Opinion Survey in Turkey", Sosyoekonomi, Vol. 28(43), 89-105. 